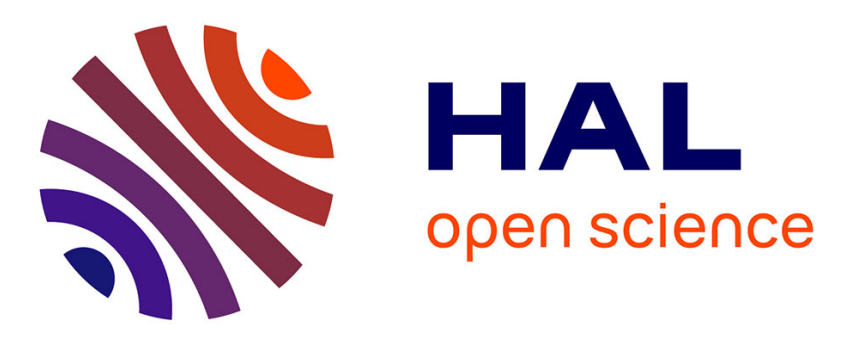

\title{
Luminescent and structural properties of ZnxMg1-xWO4 mixed crystals
}

N. Krutyak, V. Nagirnyi, D. Spassky, I. Tupitsyna, A. Dubovik, A. Belsky

\section{To cite this version:}

N. Krutyak, V. Nagirnyi, D. Spassky, I. Tupitsyna, A. Dubovik, et al.. Luminescent and structural properties of ZnxMg1-xWO4 mixed crystals. Radiation Measurements, 2016, 90, pp.43-46. 10.1016/j.radmeas.2016.01.007 . hal-03121675

\section{HAL Id: hal-03121675 \\ https://hal.science/hal-03121675}

Submitted on 26 Jan 2021

HAL is a multi-disciplinary open access archive for the deposit and dissemination of scientific research documents, whether they are published or not. The documents may come from teaching and research institutions in France or abroad, or from public or private research centers.
L'archive ouverte pluridisciplinaire HAL, est destinée au dépôt et à la diffusion de documents scientifiques de niveau recherche, publiés ou non, émanant des établissements d'enseignement et de recherche français ou étrangers, des laboratoires publics ou privés. 
See discussions, stats, and author profiles for this publication at: https://www.researchgate.net/publication/289684926

\section{Luminescent and structural properties of ZnxMg1-xWO4 mixed crystals}

Article in Radiation Measurements · January 2016

DOI: 10.1016/j.radmeas.2016.01.007

READS

53

6 authors, including:

\section{Spassky}

Lomonosov Moscow State University

135 PUBLICATIONS 915 CITATIONS

SEE PROFILE
Irina A. Tupitsyna

National Academy of Sciences of Ukraine 60 PUBLICATIONS 374 CITATIONS

SEE PROFILE 


\section{Accepted Manuscript}

Luminescent and structural properties of $\mathrm{Zn}_{\mathrm{x}} \mathrm{Mg}_{1-\mathrm{x}} \mathrm{WO}_{4}$ mixed crystals

N. Krutyak, V. Nagirnyi, D. Spassky, I. Tupitsyna, A. Dubovik, A. Belsky

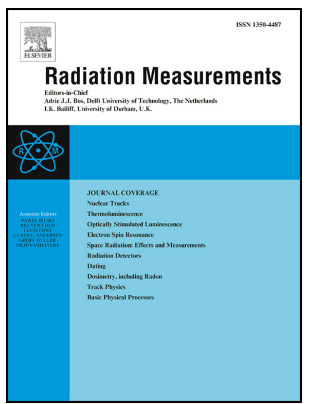

PII:

$$
\text { S1350-4487(16)30007-5 }
$$

DOI:

10.1016/j.radmeas.2016.01.007

Reference: $\quad$ RM 5534

To appear in: Radiation Measurements

Received Date: 25 October 2015

Revised Date: 17 December 2015

Accepted Date: 6 January 2016

Please cite this article as: Krutyak, N., Nagirnyi, V., Spassky, D., Tupitsyna, I., Dubovik, A., Belsky, A., Luminescent and structural properties of $\mathrm{Zn}_{\mathrm{X}} \mathrm{Mg}_{1-\mathrm{x}} \mathrm{WO}_{4}$ mixed crystals, Radiation Measurements (2016), doi: 10.1016/j.radmeas.2016.01.007.

This is a PDF file of an unedited manuscript that has been accepted for publication. As a service to our customers we are providing this early version of the manuscript. The manuscript will undergo copyediting, typesetting, and review of the resulting proof before it is published in its final form. Please note that during the production process errors may be discovered which could affect the content, and all legal disclaimers that apply to the journal pertain. 


\title{
Luminescent and structural properties of $\mathrm{Zn}_{\mathrm{x}} \mathrm{Mg}_{1-\mathrm{x}} \mathrm{WO}_{4}$ mixed crystals
}

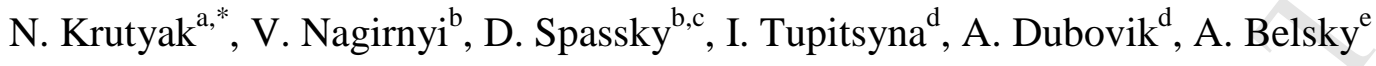 \\ ${ }^{a}$ Physics Department, Moscow State University, Leninskie Gory 1, 119991, Moscow, Russia \\ ${ }^{b}$ Institute of Physics, University of Tartu, Ravila 14 c, 50411, Tartu, Estonia \\ ${ }^{c}$ Skobeltsyn Institute of Nuclear Physics, Moscow State University, 119991, Moscow, Russia \\ ${ }^{\mathrm{d}}$ Institute for Scintillation Materials, NAS of Ukraine, 60 Lenin ave., 61001, Kharkiv, Ukraine \\ ${ }^{e}$ Institute of Light and Matter, CNRS, University Lyon1, 10 rue Ada Byron, 69622, Villeurbanne CEDEX, France
}

\begin{abstract}
The structural and luminescent properties of perspective scintillating $\mathrm{Zn}_{\mathrm{x}} \mathrm{Mg}_{1-\mathrm{x}} \mathrm{WO}_{4}$ mixed crystals were studied. The following characteristics were found to depend linearly on $\mathrm{x}$ value: the energy of several vibrational modes detected by Raman spectroscopy, the bandgap width deduced from the shift of the excitation spectrum onset of a self-trapped exciton (STE) emission, the position of thermally stimulated luminescence peaks. It is also shown that the thermal stability of the STE luminescence decreases gradually when x decreases. These data indicate that each $\mathrm{Zn}_{\mathrm{x}} \mathrm{Mg}_{1-\mathrm{x}} \mathrm{WO}_{4}$ mixed crystal is not a mixture of two constituents, but possesses its original crystalline structure, as well as optical and luminescent properties.
\end{abstract}

Keywords: $\quad \mathrm{Zn}_{\mathrm{x}} \mathrm{Mg}_{1-\mathrm{x}} \mathrm{WO}_{4} \quad$ mixed crystals; Raman spectra; self-trapped excitons; thermostimulated luminescence; bandgap 


\section{Introduction}

High light output for scintillating materials is one of the main requirements for their successful application. Recently it has been demonstrated that the scintillation light yield increases in the mixed crystals relatively to the yield in their constituents. The effect is observed for the compounds with activator as well as intrinsic luminescence (Gektin et al., 2014; Spassky et al., 2014) and is presumably due to the decrease of the mean free path of charge carriers at the stage of thermalization and subsequent migration of thermalized electrons and holes.

Recently it has been demonstrated that the light output of undoped $\mathrm{Zn}_{\mathrm{x}} \mathrm{Mg}_{1-\mathrm{x}} \mathrm{WO}_{4}$ mixed crystals has a maximum value at $x=0.5$ at $\mathrm{T}=300 \mathrm{~K}$. The luminescence of these crystals is connected with the emission from excitons, which are self-trapped at $\mathrm{WO}_{6}$ complexes. Using the data of luminescence spectroscopy and by means of the numerical simulation it has been shown that the enhancement is connected with the increase of the probability of exciton formation from separated geminate e-h pairs as far as the distance between thermalized electrons and holes is minimal at the value of $x=0.5$ (Spassky et al., 2014). The constituents of the $\mathrm{MgWO}_{4}$ and $\mathrm{ZnWO}_{4}$ mixed crystals belong to the same wolframite structural type (space group $P 2 / c$ ) that allows to expect the $\mathrm{Zn}_{\mathrm{x}} \mathrm{Mg}_{1-\mathrm{x}} \mathrm{WO}_{4}$ crystals to have the same structure through the whole set of $\mathrm{x}$ values. The abovementioned properties allow considering the $\mathrm{Zn}_{\mathrm{x}} \mathrm{Mg}_{1-\mathrm{x}} \mathrm{WO}_{4}$ crystals as a new and promising scintillating material for various applications, including cryogenic scintillating detectors.

In this work we present new experimental data on $\mathrm{Zn}_{\mathrm{x}} \mathrm{Mg}_{1-\mathrm{x}} \mathrm{WO}_{4}$ mixed crystals, including the results of Raman spectroscopy and thermostimulated luminescence (TSL) 
studies. Linear dependences of a set of structural and luminescent parameters on $\mathrm{x}$ value will be demonstrated.

\section{Experimental details}

The set of $\mathrm{Zn}_{\mathrm{x}} \mathrm{Mg}_{1-\mathrm{x}} \mathrm{WO}_{4}(x=0.3,0.4,0.5,0.6,0.7,0.8,0.9,0.95,1)$ single crystals were grown by the Czochralski method from platinum crucibles using high-frequency heating. Growth conditions were the following: gradient $\Delta \mathrm{Tz} \leq 10-20 \mathrm{deg} / \mathrm{cm}$, pulling speed $v=1.2-$ $1.4 \mathrm{~mm} / \mathrm{hr}$, weight gain $\mathrm{dm} / \mathrm{dt}=2.0-2.5 \mathrm{~g} / \mathrm{hr}$. The $\mathrm{MgWO}_{4}$ single crystal was grown from melted flux solution by pulling on a rotating seed from a platinum crucible.

The Raman measurements were made using a micro Raman spectroscope Renishaw inVia at wavelength $514 \mathrm{~nm}$. A deuterium $400 \mathrm{~W}$ discharge lamp DDS-400 and a doublequartz prism monochromator DMR-4 were used for measuring the luminescence excitation spectra near the fundamental absorption edge (3.4-4.4 eV) at room temperature.

The measurements of radioluminescence spectra were carried out under irradiation by an $\mathrm{X}$-ray source with a tungsten anode operating at $\mathrm{U}=30 \mathrm{keV}$. The spectra were registered using Shamrock 500i spectrograph equipped with Newton EMCCD DU970P. TSL glow curves and spectra were recorded in the temperature region $80-470 \mathrm{~K}$ after X-ray irradiation of samples for $600 \mathrm{~s}$ at $\mathrm{T}=80 \mathrm{~K}$.

\section{Results and discussion}

\subsection{Raman spectroscopy data}

The phase composition of $\mathrm{Zn}_{\mathrm{X}} \mathrm{Mg}_{1-\mathrm{x}} \mathrm{WO}_{4}$ was controlled by X-ray phase analysis. All grown crystals are crystallized in the wolframite structural type. According to a group theory, 
the wolframite structure presents 18 Raman active modes $-8 \mathrm{~A}_{\mathrm{g}}+10 \mathrm{~B}_{\mathrm{g}}$. In these compounds, due to the differences in valence and mass between $\mathrm{W}^{6+}$ and $\mathrm{A}^{2+}$ cations, the lattice dynamics can be understood assuming two kinds of modes (Ruiz-Fuertes et al., 2011). Six of them are related to the vibrations inside the covalently bounded $\mathrm{WO}_{6}$ octahedra (so-called internal modes) and other modes originate as motions of the A cations against the $\mathrm{WO}_{6}$ units (external modes). The internal modes have higher frequencies than the external ones and usually there is a phonon gap between them.

The Raman spectra of $\mathrm{Zn}_{\mathrm{x}} \mathrm{Mg}_{1-\mathrm{x}} \mathrm{WO}_{4}$ mixed crystals are presented in Fig. 1. It should be noted, that some of the modes were not observed due to the uncertain orientation of the samples or low intensity of these Raman modes. The frequencies of detected Raman bands in $\mathrm{ZnWO}_{4}(\mathrm{x}=1), \mathrm{MgWO}_{4}(\mathrm{x}=0)$ and $\mathrm{Zn}_{0.5} \mathrm{Mg}_{0.5} \mathrm{WO}_{4}$ as well as their attribution to the corresponding modes are listed in Table 1. It can be seen from Table 1 that the observed Raman-active modes for $\mathrm{ZnWO}_{4}$ and $\mathrm{MgWO}_{4}$ are in good agreement with literature data (Liu et al., 1988; Fomichev et al., 1994; Ruiz-Fuertez et al., 2011). The frequencies 909 ( $\left.\mathrm{A}_{\mathrm{g}}\right), 788$ $\left(\mathrm{B}_{\mathrm{g}}\right), 708.5\left(\mathrm{~A}_{\mathrm{g}}\right), 677\left(\mathrm{~B}_{\mathrm{g}}\right), 409\left(\mathrm{~A}_{\mathrm{g}}\right)$ and $341.4\left(\mathrm{~A}_{\mathrm{g}}\right) \mathrm{cm}^{-1}$ in $\mathrm{ZnWO}_{4}$ correspond to the stretching vibrations of $\mathrm{W}-\mathrm{O}$ atoms in the $\mathrm{WO}_{6}$ group (Liu et al., 1988; Perakis et al., 2000). The bands with the frequencies $197\left(\mathrm{~A}_{\mathrm{g}}\right), 165\left(\mathrm{~B}_{\mathrm{g}}\right), 150\left(\mathrm{~B}_{\mathrm{g}}\right)$ and $125\left(\mathrm{~A}_{\mathrm{g}}\right) \mathrm{cm}^{-1}$ are attributed to vibrations involving zinc cations (Fomichev et al., 1994). In the case of $\mathrm{MgWO}_{4}$ the internal modes are the $\mathrm{A}_{\mathrm{g}}$ modes at $420,552,713$ and $917 \mathrm{~cm}^{-1}$ and the $\mathrm{B}_{\mathrm{g}}$ modes at 684 and $809 \mathrm{~cm}^{-1}$ (Ruiz-Fuertes et al., 2011).

A strong Raman mode at $\sim 910 \mathrm{~cm}^{-1}$ is typical for wolframites and corresponds to a symmetric $\mathrm{A}_{\mathrm{g}}$ internal vibration of the $\mathrm{WO}_{6}$ octahedron. Fig. 2 represents the wavenumber 
variation of the maximum position of this mode from 906 to $917 \mathrm{~cm}^{-1}$ depending on $x$ value in $\mathrm{Zn}_{\mathrm{x}} \mathrm{Mg}_{1-\mathrm{x}} \mathrm{WO}_{4}$. The dependence of the mode maximum on $x$ is linear (see Fig. 2, inset). The same tendency is observed for the Raman mode at $\sim 120 \mathrm{~cm}^{-1}$ connected with external vibrations involving cations. The observed linear shift is caused by the linear increase of cell parameters with the increase of $\mathrm{x}$ value. The intensity of Raman modes under discussion decreases with the increase of $x$ value in both cases. The width of the internal vibration mode increases slightly whereas that of the external vibrations increases drastically reflecting the gradual substitution of $\mathrm{Zn}$ by $\mathrm{Mg}$ cation. Presented data indicate that the $\mathrm{Zn}_{\mathrm{x}} \mathrm{Mg}_{1} \mathrm{x} \mathrm{WO}_{4}$ mixed crystals cannot be considered as mixtures of two constituent crystals, but a new unique crystal is formed at each $\mathrm{x}$ value. This statement is supported by the fact, that changes in $\mathrm{x}$ values result rather in a gradual shift of the Raman mode maxima than in the redistribution of the intensities of Raman modes, characteristic for each of constituent crystals, which could be expected in the case of phase mixtures.

\subsection{Luminescence spectroscopy data}

$\mathrm{Zn}_{\mathrm{x}} \mathrm{Mg}_{1-\mathrm{x}} \mathrm{WO}_{4}$ mixed crystals under $\mathrm{X}$-ray excitation are characterized by a single emission band at $495 \mathrm{~nm}$, which is connected with the self-trapped exciton (STE) emission. The position of the STE-related band and its decay characteristics are similar for all studied crystals. It indicates an insignificant influence of cation electronic states on the formation of energy bands in the vicinity of the bandgap that is confirmed by the band structure calculations for $\mathrm{ZnWO}_{4}$ and $\mathrm{MgWO}_{4}$ (Khyzhun et al., 2013; Ruiz-Fuertes et al., 2012).

The crystal bandgap can be estimated from the excitation spectra of the STE luminescence because the onset of these spectra is correlated to the fundamental absorption 
edge. The excitation spectra for all the samples studied in the energy region 3.4-4.4 eV are presented in Fig. 3. A gradual low-energy shift of the fundamental absorption edge with the increase of $x$ from 0 to 1 is observed. Actually the bandgap for $\mathrm{MgWO}_{4}\left(\mathrm{E}_{\mathrm{g}}=5.0 \mathrm{eV}\right)$ is greater than for $\mathrm{ZnWO}_{4}\left(\mathrm{E}_{\mathrm{g}}=4.5 \mathrm{eV}\right)$ (Kolobanov et al., 2002). Therefore, this shift indicates the linear increase of the optical bandgap with the decrease of $x$ value, which is estimated from the onset of excitation spectra (see. Fig. 3 inset).

The temperature dependences of the STE luminescence intensity for $\mathrm{Zn}_{\mathrm{x}} \mathrm{Mg}_{1-\mathrm{x}} \mathrm{WO}_{4}$ are shown in Fig. 4. Emission spectra were measured under X-ray radiation in the temperature region $80-470 \mathrm{~K}$ then integrated. A distinct decrease of the emission intensity above $\sim 250 \mathrm{~K}$ is connected with the temperature quenching of the luminescence. It follows from Fig. 4 that both the stability of the STE emission and the width of the bandgap are increased in the same sequence of mixed crystals. One can suggest that the exciton bonding energy increases along with the bandgap width increase in the mixed crystals studied. Different thermal stability of excitons localized at $\mathrm{WO}_{4}$ complexes has also been observed in a sequence of homologue scheelites (Laasner et al., 2015).

Temperature dependences measured under X-ray excitation cannot be fitted by the Mott formula. The deviations appear due to the occurrence of different processes competitive to the STE emission, e.g. nonradiative relaxation of separated charge carriers on crystal defects, trapping of charge carriers, crystal structure defect creation under X-ray irradiation. The latter process is manifested in the degradation of luminescence intensity down to $80 \%$ of initial intensity at $\mathrm{T}=88 \mathrm{~K}$ in the $\mathrm{Zn}_{0.6} \mathrm{Mg}_{0.4} \mathrm{WO}_{4}$ sample under continuous $\mathrm{X}$-ray irradiation during $600 \mathrm{~s}$ (Fig. 4, inset). These defects are not stable at higher temperatures and the corresponding 
luminescence degradation is not observed. Similar effect has been observed for $\mathrm{PbWO}_{4}$ at low temperatures and resulted in the degradation of the scintillation light yield (Burachas et al., 2010). Taking into account that tungstates are considered for the application in cryogenic scintillating detectors, the poor radiation hardness could become a considerable problem for their application.

In Fig. 5, the TSL curves of $\mathrm{Zn}_{\mathrm{x}} \mathrm{Mg}_{1-\mathrm{x}} \mathrm{WO}_{4}$ are presented. Each of the studied samples demonstrates a set of TSL peaks. At $\mathrm{x}=1\left(\mathrm{ZnWO}_{4}\right)$ the intensive peak at $130 \mathrm{~K}$ and two weak peaks at 170 and $230 \mathrm{~K}$ are observed. The peak at $230 \mathrm{~K}$ is generally ascribed to the emission related to the Mo impurity contaminating the crystal, while the peak at $170 \mathrm{~K}$ is attributed to the presence of $\mathrm{Li}$ as a satellite impurity in the crystal structure (Krutyak et al., 2013). At $\mathrm{x}=0$ $\left(\mathrm{MgWO}_{4}\right)$ only one TSL peak at $170 \mathrm{~K}$ is observed. It should be noted that the peaks at $170 \mathrm{~K}$ in zinc and magnesium tungstates have different origin in spite of the same position. Actually throughout the set of mixed crystals the tendency for the linear shift of peak positions to higher temperatures with the decrease of $\mathrm{x}$ is clearly observed. The shift indicates the increase of trap depths and is correlated to the increase of bandgap width. In the TSL curves, we indicate by lines two sets of TSL peaks, which demonstrate linear shifts of their positions on $\mathrm{x}$ value.

The most intensive TSL peaks are characteristic for the intermediate values of $x-$ $\mathrm{Zn}_{0.7} \mathrm{Mg}_{0.3} \mathrm{WO}_{4}$ and $\mathrm{Zn}_{0.6} \mathrm{Mg}_{0.2} \mathrm{WO}_{4}$. It may be ascribed to the partial disorder of crystal's structure in the mixed crystals that results in the increase of traps concentration.

\section{Conclusions}


A gradual shift of Raman bands following the changes of lattice parameters was observed in Raman spectra of $\mathrm{Zn}_{\mathrm{x}} \mathrm{Mg}_{1-\mathrm{x}} \mathrm{WO}_{4}$ mixed crystals. The studies of the excitation spectra of the STE emission revealed the linear modification of the bandgap with $x$ value. The TSL glow curves demonstrate a high-temperature shift in peak positions with the increase of $x$ value, thus indicating the increase of trap depth and, consequently, providing additional arguments in favor of bandgap width increase. The degradation of luminescence under X-ray irradiation was detected at $\mathrm{T}=80 \mathrm{~K}$ and ascribed to the creation of crystal structure defects. The data provided indicate that each $\mathrm{Zn}_{\mathrm{x}} \mathrm{Mg}_{1-\mathrm{x}} \mathrm{WO}_{4}$ mixed crystal is not a mixture of two constituents, but possesses its original crystalline structure, as well as optical and luminescent properties.

\section{Acknowledgement}

Financial support of grants of the RFASInnovations № RFMEFI61614X0006, RFBR 1502-07825-a, Mobilitas ESF (MTT83) and Estonian investigation council (IUT02-26) is gratefully acknowledged.

\section{References}

Burachas, S., Ippolitov, M., Manko, V., Nikulin, S., Vasiliev, A., Apanasenko, A., Vasiliev, A., Uzunian, A., Tamulaitis, G., (2010) Temperature dependence of radiation hardness of lead tungstate (PWO) scintillation crystals, Rad. Meas., vol. 45, 83-88.

Fomichev, V.V., Kondratov, O.I., (1994) Vibrational spectra of compounds with the wolframite structure, Spectrochimica Acta vol. 50 A, 1113-1120. 
Gektin, A.V., Belsky, A.N., Vasilev, A.N., (2014) Scintillation Efficiency Improvement by Mixed Crystal Use, IEEE Trans. Nucl. Sc. vol. 61, 262-270.

Khyzhun, O.Y., Bekenev, V.L., Atuchin, V.V., Galashov, E.N., Shlegel, V.N., (2013) Electronic properties of $\mathrm{ZnWO}_{4}$ based on ab initio FP-LAPW band-structure calculations and X-ray spectroscopy data, Mater. Chem. Phys. vol. 140, 588-595.

Kolobanov, V.N., Kamenskikh, I.A., Mikhailin, V.V., Shpinkov, I.N., Spassky, D.A., Zadneprovsky, B.I., Potkin, L.I., Zimmerer, G., (2002) Optical and luminescent properties of anisotropic tungstate crystals, Nucl. Instr. Meth. Phys. Res. A. vol. 486, 496-503.

Krutyak, N.R., Mikhailin, V.V., Vasil'ev, A.N., Spassky, D.A., Tupitsyna, I.A., Dubovik, A.M., Galashov, E.N., Shlegel, V.N, Belsky, A.N., (2013) The features of energy transfer to the emission centers in $\mathrm{ZnWO}_{4}$ and $\mathrm{ZnWO}_{4}: \mathrm{Mo}$, J. of Lum., vol. 144, 105-111.

Laasner, R., Nagirnyi, V., Vielhauer, S., Kirm, M., Spassky, D., Sirutkaitis, V., Grigonis, R., Vasil'ev, A.N., (2015) Cation influence on exciton localization in homologue scheelites, $J$. Phys. Cond. Mat. vol. 27, 385501.

Liu, Y., Wang, H., Chen, G., Zhou, Y.D., Gu, B.Y., Hu, B.Q., (1988) Analysis of Raman spectra of $\mathrm{ZnWO}_{4}$ single crystals, J. Appl. Phys. vol. 64, 4651-4653.

Perakis, A., Sarantopoulou, E., Raptis, C., (2000) Pressure and temperature dependent Raman study of $\mathrm{ZnWO}_{4}$, High Pres. Research, vol. 18, 181-187.

Ruiz-Fuertes, J., Errandonea, D., López-Moreno, S., González, J., Gomis, O., Vilaplana, R., Manjón, F.J., Muñoz, A., Rodríguez-Hernández, P., Friedrich, A., Tupitsyna, I.A., Nagornaya, L.L., (2011) High-pressure Raman spectroscopy and lattice-dynamics 
calculations on scintillating $\mathrm{MgWO}_{4}$ : Comparison with isomorphic compounds, Phys. Rev. $B$, vol. 83, 214112 .

Ruiz-Fuertes, J., Lopez-Moreno, S., Lopez-Solano, J., Errandonea, D., Segura, A., LacombaPerales, R., Munoz, A., Radescu, S., Rodriguez-Hernandez, P., Gospodinov, M., Nagornaya, L.L., Tu, C.Y., (2012) Pressure effects on the electronic and optical properties of $A \mathrm{WO}_{4}$ wolframites $(A=\mathrm{Cd}, \mathrm{Mg}, \mathrm{Mn}$, and $\mathrm{Zn})$ : The distinctive behavior of multiferroic $\mathrm{MnWO}_{4}$, Phys. Rev. B, vol. 86, 125202.

Spassky, D., Omelkov, S., Mägi, H., Mikhailin, V., Vasil'ev, A., Krutyak, N., Tupitsyna, I., Dubovik, A., Yakubovskaya, A., Belsky, A., (2014) Energy transfer in solid solutions $\mathrm{Zn}_{\mathrm{x}} \mathrm{Mg}_{1-\mathrm{x}} \mathrm{WO}_{4}$, Optical Materials vol. 36, 1660-1664. 


\section{Figure captions}

Fig. 1 The Raman spectra of $\mathrm{Zn}_{\mathrm{x}} \mathrm{Mg}_{1-\mathrm{x}} \mathrm{WO}_{4}$ crystals at $\mathrm{T}=300 \mathrm{~K}$.

Fig. 2 The modification of Raman bands at $\sim 120$ and $910 \mathrm{~cm}^{-1}$ with $\mathrm{x}$ value for $\mathrm{Zn}_{\mathrm{x}} \mathrm{Mg}_{1-\mathrm{x}} \mathrm{WO}_{4}$ crystals. Inset: dependence of the maximum of band at $\sim 910 \mathrm{~cm}^{-1}$ on $x$.

Fig. 3 Excitation spectra of STE luminescence of $\mathrm{Zn}_{\mathrm{x}} \mathrm{Mg}_{1-\mathrm{x}} \mathrm{WO}_{4}$ crystals at $\lambda_{\mathrm{ex}}=500 \mathrm{~nm}, \mathrm{~T}=$ $300 \mathrm{~K}$. Inset: dependence of bandgap width $\mathrm{E}_{\mathrm{g}}$ on $x$ value. $\mathrm{E}_{\mathrm{g}}$ is estimated from the interpolation of the onset of spectra to the abscissa axis.

Fig. 4 Temperature dependences of luminescence intensity under X-ray excitation for $\mathrm{Zn}_{\mathrm{x}} \mathrm{Mg}_{1-}$ ${ }_{\mathrm{x}} \mathrm{WO}_{4}$ crystals. Inset: intensity degradation after $600 \mathrm{~s}$ of irradiation with $\mathrm{X}$-rays at different temperatures for $\mathrm{Zn}_{0.6} \mathrm{Mg}_{0.4} \mathrm{WO}_{4}$.

Fig. 5 TSL curves of $\mathrm{Zn}_{\mathrm{x}} \mathrm{Mg}_{1-\mathrm{x}} \mathrm{WO}_{4}$ crystals after X-ray irradiation at $\mathrm{T}=80 \mathrm{~K}$ for $600 \mathrm{~s}$. 
12

Table 1 Vibrational frequencies of some $\mathrm{Zn}_{\mathrm{x}} \mathrm{Mg}_{1-\mathrm{x}} \mathrm{WO}_{4}$ compositions with the wolframite structure

\begin{tabular}{|c|c|c|c|c|c|c|}
\hline \multicolumn{3}{|c|}{$\mathrm{ZnWO}_{4}$} & \multicolumn{3}{|c|}{$\mathrm{MgWO}_{4}$} & \multirow{3}{*}{$\begin{array}{c}\mathrm{Zn}_{0.5} \mathrm{Mg}_{0.5} \mathrm{WO}_{4} \\
\omega\left(\mathrm{cm}^{-1}\right) \\
\text { Present }\end{array}$} \\
\hline \multicolumn{2}{|c|}{$\omega\left(\mathrm{cm}^{-1}\right)$} & Mode & \multicolumn{2}{|c|}{$\omega\left(\mathrm{cm}^{-1}\right)$} & Mode & \\
\hline \multirow{4}{*}{\begin{tabular}{|c|} 
Present \\
122 \\
\end{tabular}} & \multicolumn{2}{|c|}{ Liu, 1988} & Present & Ruiz-Fu & es, 2010 & \\
\hline & \multirow[t]{3}{*}{124} & \multirow[t]{3}{*}{$\mathrm{A}_{\mathrm{g}}$} & & & & 128 \\
\hline & & & 154 & 155.9 & $\mathrm{~A}_{\mathrm{g}}$ & 158 \\
\hline & & & & 185.1 & $\mathrm{~B}_{\mathrm{g}}$ & 186 \\
\hline 194 & 196 & $\mathrm{~A}_{g}$ & & & & \\
\hline \multirow[t]{2}{*}{274} & 276 & $\mathrm{~A}_{\mathrm{g}}$ & 277 & 277.1 & $\mathrm{~A}_{\mathrm{g}}$ & 272 \\
\hline & & & 294 & 294.1 & $\mathrm{~A}_{\mathrm{g}}$ & 294 \\
\hline \multirow[t]{2}{*}{340} & 343 & $\mathrm{~B}_{\mathrm{g}}$ & & & & 347 \\
\hline & 356 & $\mathrm{~B}_{\mathrm{g}}$ & 353 & 351.9 & $A_{g}$ & \\
\hline \multirow[t]{2}{*}{406} & 409 & $\mathrm{~A}_{g}$ & & 405.2 & $\mathrm{~B}_{\mathrm{g}}$ & \\
\hline & & & 420 & 420.4 & $\mathrm{~A}_{\mathrm{g}}$ & 416 \\
\hline 545 & 546 & $A_{g}$ & 551 & 551.6 & $\mathrm{~A}_{\mathrm{g}}$ & 547 \\
\hline 708 & 711 & $A_{g}$ & 710 & 713.2 & $\mathrm{~A}_{\mathrm{g}}$ & 709 \\
\hline 786 & 788 & $\mathrm{~B}_{\mathrm{g}}$ & & & & \\
\hline 906 & 909 & $A_{g}$ & 917 & 916.8 & $A_{g}$ & 913 \\
\hline
\end{tabular}




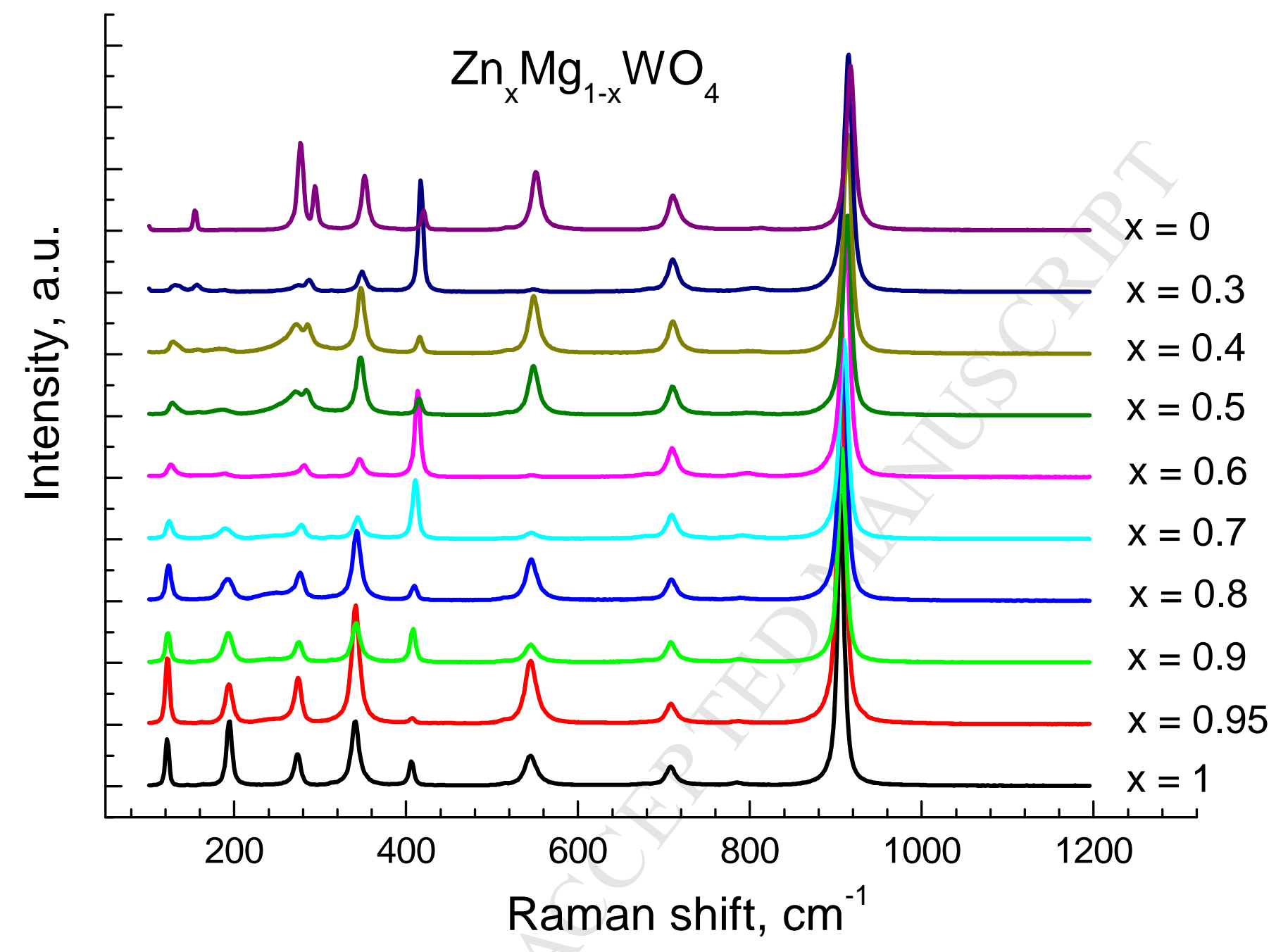




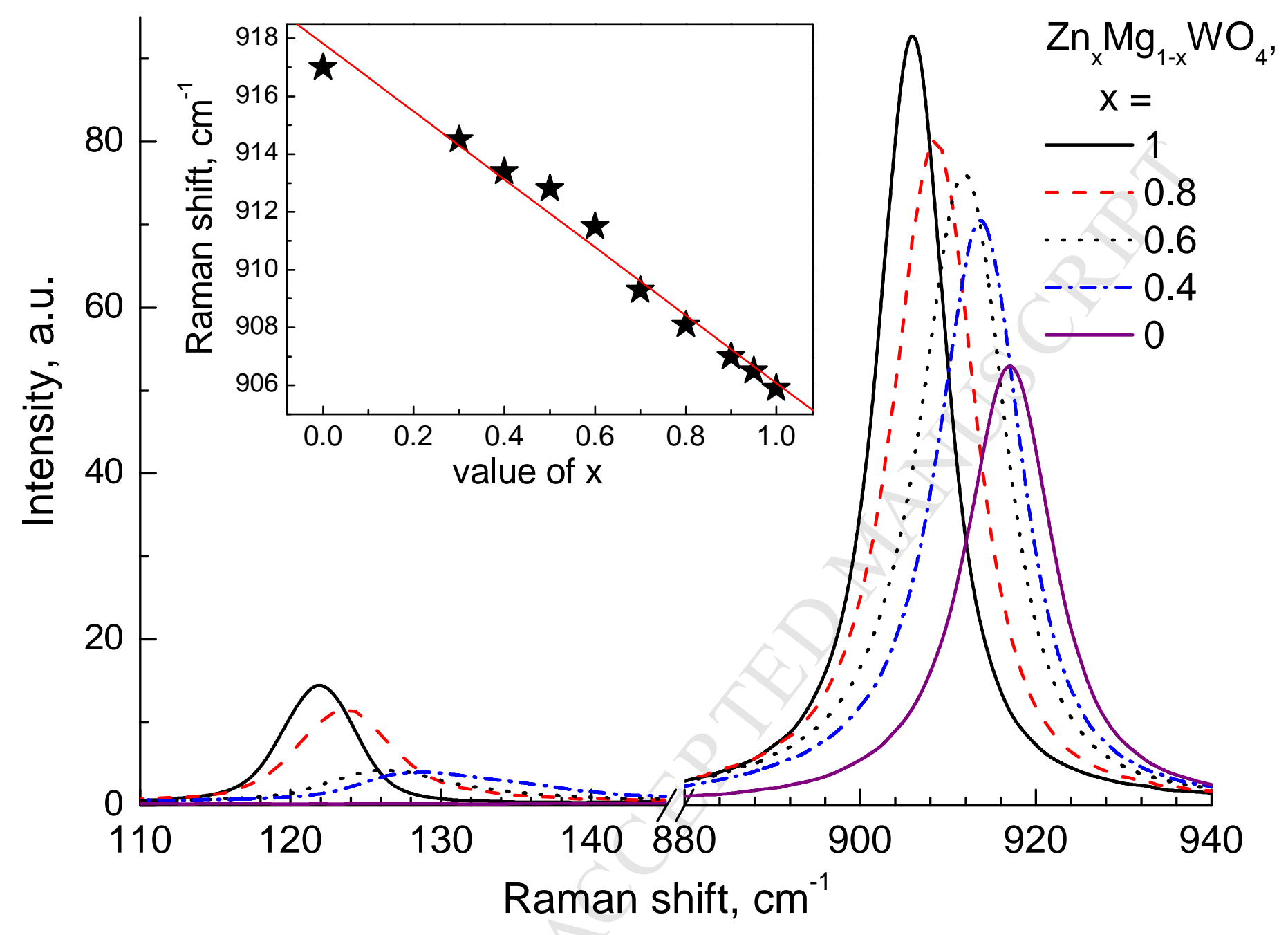




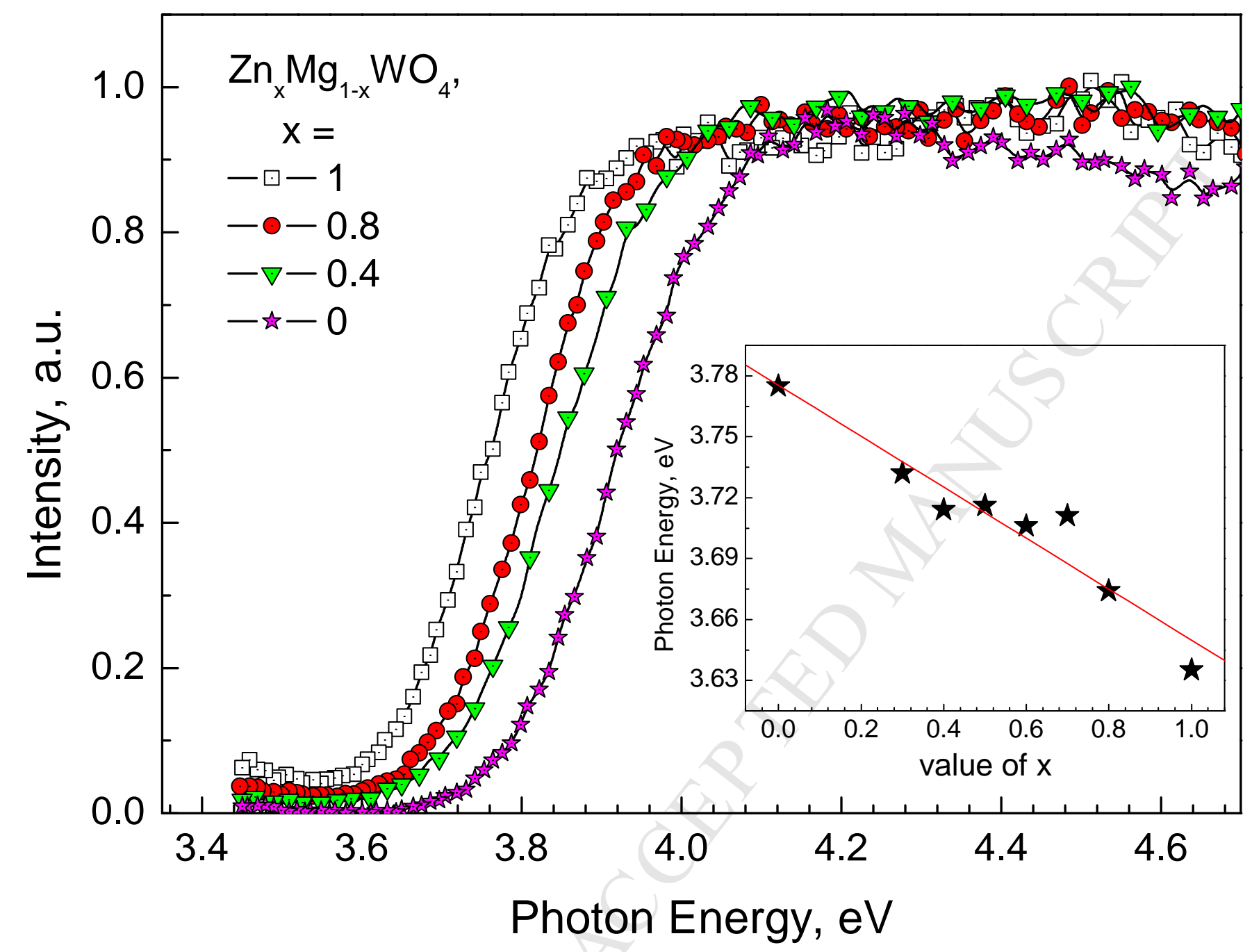




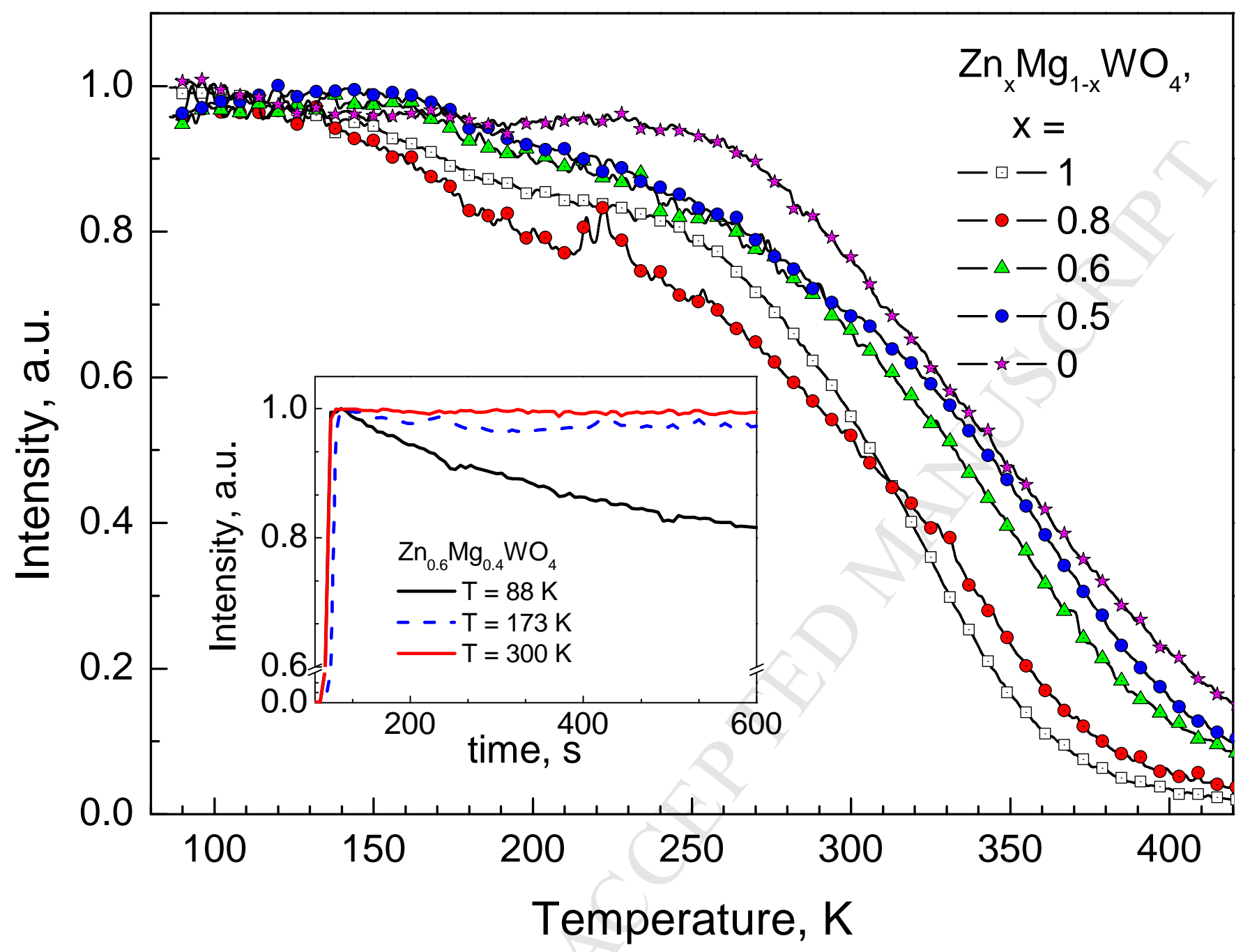




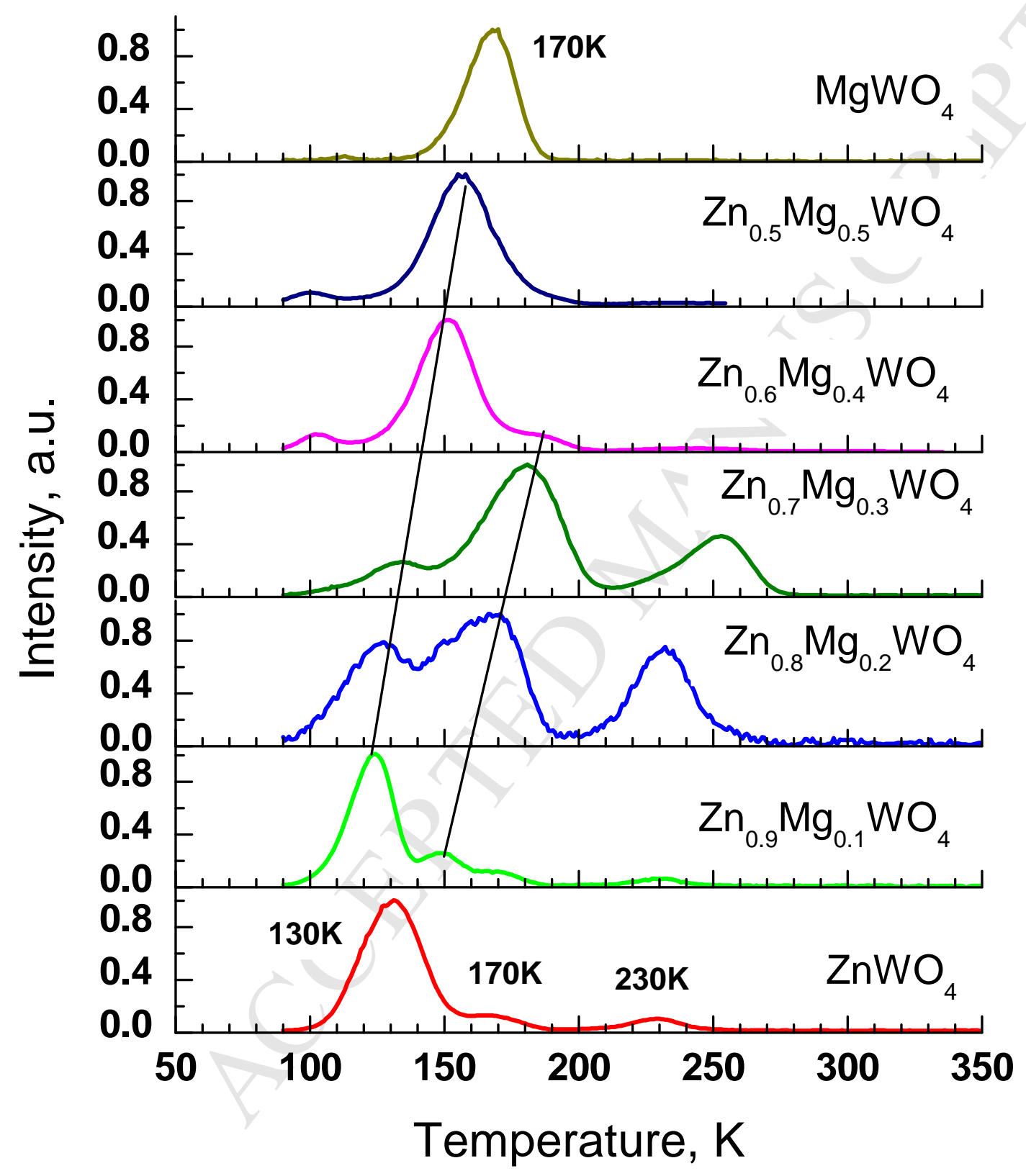


The structural and luminescent properties of $\mathrm{Zn}_{\mathrm{x}} \mathrm{Mg}_{1-\mathrm{x}} \mathrm{WO}_{4}$ were studied.

The energy of Raman modes, the bandgap width, TSL peak position linearly depend on $\mathrm{x}$. Each $\mathrm{Zn}_{\mathrm{x}} \mathrm{Mg}_{1-\mathrm{x}} \mathrm{WO}_{4}$ possesses its original crystalline structure. 